32. Brock JH 1980 Lactoferrin in human milk: its role in iron absorption and protection against enteric infection in the newborn infant. Arch Dis Child 55:417-421

33. Bläckberg $L$, Hernell $O 1980$ Isolation of lactoferrin from human whey by a single chromatographic step. FEBS Lett 109:180-184

34. Ford JE, Law BA, Marshall VME, Reiter B 1977 Influence of the heat treatment of human milk on some of its protective constituents. J Pediatr 90:29-35

35. Fomon SJ, Janghorbani M, Ting BTG, Ziegler EE, Rogers RR, Nelson SE,
Ostegaard LS, Edwards BB 1988 Erythrocyte incorporation of ingested 58iron by infants. Pediatr Res 24:20-24

36. Bothwell TH, Charlton RW, Cook JD, Finch CA 1979 Iron Metabolism in Man. Blackwell Scientific, Oxford, pp 256-283

37. Gislason J, Jones B, Lönnerdal B, Hambraeus L 1992 Iron absorption differs in piglets fed extrinsically and intrinsically 59Fe-labeled sow's milk. J Nutr 122:1287-1292

38. Fransson GB, Lönnerdal B 1980 Iron in human milk. J Pediatr 96:380-384

\title{
Announcement
}

\section{4th Congress of the European Society for Pediatric Neurosurgery}

The 14th Congress of the European Society for Pediatric Neurosurgery will be held in Lyon, France from September 21 to 23, 1994. For further information, contact Professor Claude Lapras, Hôpital Neurologique, 59 Boulevard Pinel, Lyon Cedex 03, France, phone (33) 723571 94, fax (33) 72357300. 